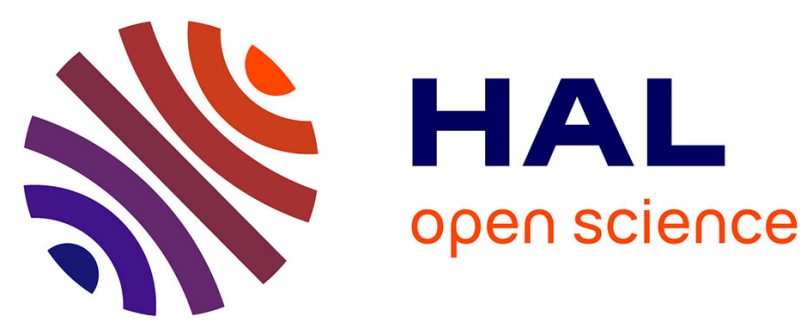

\title{
New psychoactive substance cocktail in an intensive care intoxication case elucidated by molecular networking
}

\author{
Romain Pelletier, Brendan Le Dare, Loic Grandin, Aurélien Couette,
} Pierre-Jean Ferron, Isabelle Morel, Thomas Gicquel

\section{- To cite this version:}

Romain Pelletier, Brendan Le Dare, Loic Grandin, Aurélien Couette, Pierre-Jean Ferron, et al.. New psychoactive substance cocktail in an intensive care intoxication case elucidated by molecular networking. Clinical Toxicology, 2022, 60 (1), pp.122-125. 10.1080/15563650.2021.1931693 . hal-03281618

\section{HAL Id: hal-03281618 \\ https://hal.science/hal-03281618}

Submitted on 30 Sep 2021

HAL is a multi-disciplinary open access archive for the deposit and dissemination of scientific research documents, whether they are published or not. The documents may come from teaching and research institutions in France or abroad, or from public or private research centers.
L'archive ouverte pluridisciplinaire HAL, est destinée au dépôt et à la diffusion de documents scientifiques de niveau recherche, publiés ou non, émanant des établissements d'enseignement et de recherche français ou étrangers, des laboratoires publics ou privés. 
New psychoactive substance cocktail in an intensive care intoxication case elucidated by molecular networking

Romain Pelletier ${ }^{1}$, Brendan Le Daré ${ }^{2}{ }^{3}$, Loic Grandin ${ }^{4}$, Aurélien Couette ${ }^{1}$, Pierre-Jean Ferron ${ }^{2}$, Isabelle Morel ${ }^{12}$, Thomas Gicquel ${ }^{1}{ }^{2}$

1 Forensic and Clinical toxicology laboratory, CHU Rennes, Rennes, France.

2 Institut NuMeCan (Nutrition, Metabolisms and Cancer), Univ Rennes, INSERM, INRAE, CHU Rennes, Rennes, France.

3 Pharmacy, Rennes University Hospital, Rennes, France.

4 Department of Emergency Medicine, Pontchaillou, CHU Rennes, Rennes, France. 
1

2

3

4

6

7

8

ABSTRACT:

Case details: a 37-year-old man with a history of drug abuse was discovered with several bags labelled as research chemicals around him and traces of powder on his nose. He was rehydrated, intubated and admitted to the intensive care unit. Urine and drug were analyzed by liquid chromatography-mass spectrometry for NPS identification. Several NPS were quantified in urine: 3-OH-PCP at $12085 \mathrm{mg} / \mathrm{L}, 3-\mathrm{MeO}-\mathrm{PCP}$ at $1100 \mathrm{mg} / \mathrm{L}, 2 \mathrm{~F}-\mathrm{DCK}$ at $147 \mathrm{mg} / \mathrm{L}, \mathrm{N}-$ ethylhexedrone at $165 \mathrm{mg} / \mathrm{L}$ and CMC at $48 \mathrm{mg} / \mathrm{L}$. Using a bio-informatic approach, a molecular network was built to confirm the consumption of powders contained in the bags by comparison with patient's urine.

Discussion: this case illustrates the interest of molecular networking to (i) perform sample-tosample comparison, (ii) target quantification methods and (iii) allow proper management to confirm the relevance of the treatment. 


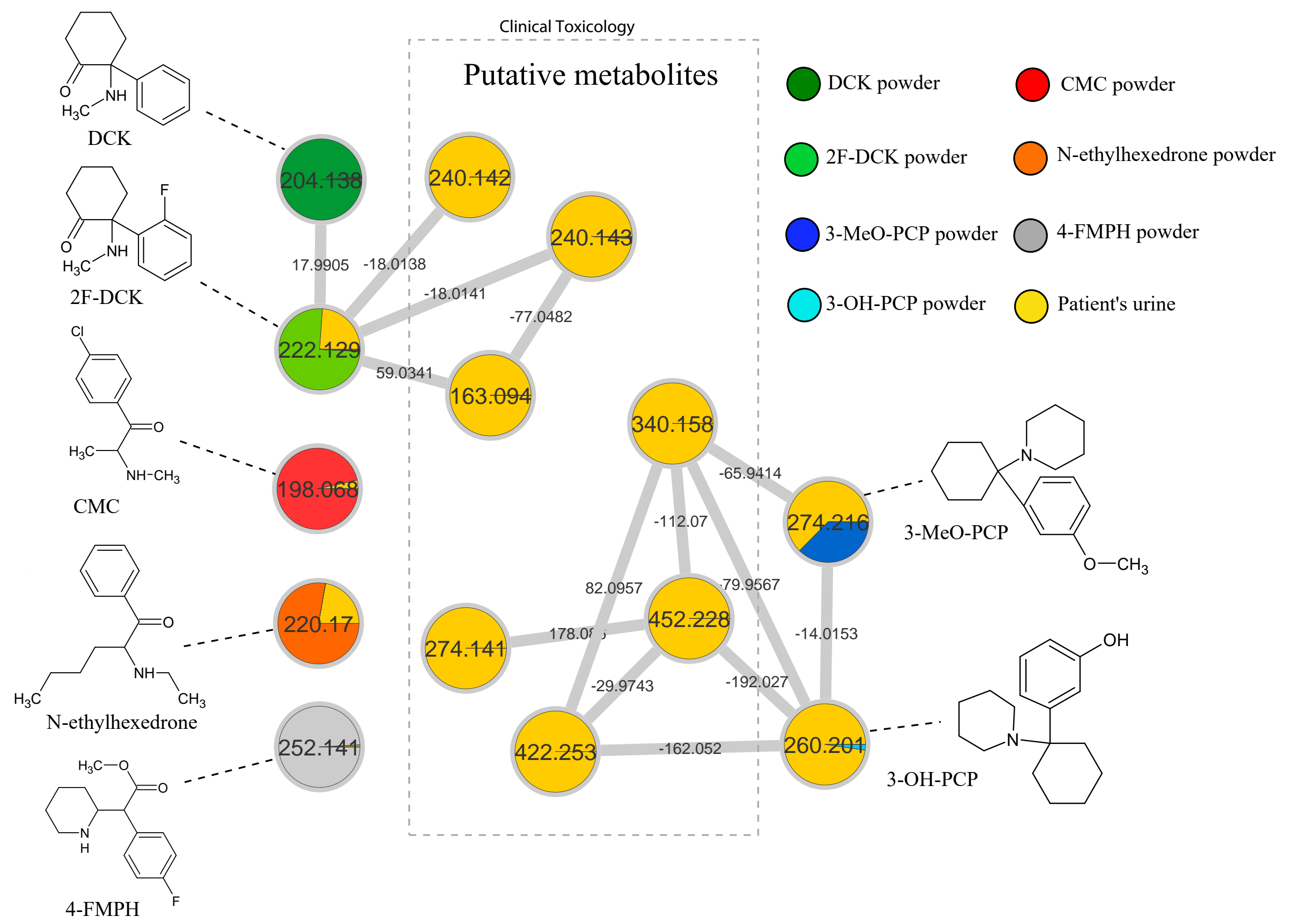




\begin{abstract}
The recreational use of new psychoactive substances (NPS) is increasing worldwide. Among them, the arylcyclohexylamine family including phencyclidine (PCP) and ketamine derivatives is increasing and emerging worldwide [1] and also in France [2]. Here, we aimed (i) to describe clinical and biological findings of a rare multiple NPS intoxication involving arylcyclohexylamine derivatives and (ii) to show the interest of molecular networking in the identification of the responsible substances. The case report was approved by the research ethics committee of Rennes University Hospital.
\end{abstract}

The case was a 37-year-old man with a history of depressive syndrome, opioid addiction, and nasal ketamine, $\mathrm{N}$-ethylhexedrone and other dissociative drug abuse. His usual treatment included mianserine (30 mg/day), extended release lithium (400 mg/day), clomipramine (75 mg/day), and buprenorphine (16 $\mathrm{mg} /$ day). He was discovered with several bags labelled as research chemicals around him and traces of powder on his nose. He was rehydrated, intubated and ventilated on etomidate and suxamethonium upon the arrival of the mobile medical emergency unit and then sedated with propofol and midazolam. After being taken in charge by the mobile emergency team, the patient was admitted to the intensive care unit (ICU) (Saint-Malo hospital, France). The patient's clinical and biological parameters during the initial clinical examination and in ICU are summarized in Table 1. The patient did not provide any information about the molecules taken, nor even on the ingested dose.

Urine, drug powders and plasma (at day +4 ) were sent to our reference toxicology laboratory in order to investigate the illicit drugs and NPS implication in this context. Unfortunately, the plasma sample used for biochemistry parameters (Saint-Malo hospital) was no longer available for NPS quantitation.

Molecular networking (MN) is a bioinformatics tool allowing presentation of untargeted tandem mass spectrometry data under graphical form. Each node represents both the ion and its associated 
fragmentation spectrum. The links between the nodes indicate similarities between spectra. Moreover, MN allows sample-to-sample comparison in a semi-quantitative manner. Our routine toxicological screening is an untargeted method allowing (i) the detection of mass between 150 and $1000 \mathrm{~m} / \mathrm{z}$, in positive and negative ionization and (ii) the identification against a library of about 1500 toxicological compounds. As molecular 3 networking method is based on the same principle with a mass range restricted to the only molecules of interest and their known metabolites, we here detected masses between 150 and $450 \mathrm{~m} / \mathrm{z}$ using only positive ionization. Molecular networking has already proven to be a powerful tool for identifying NPS from drug seizures [3] and biological samples as exemplified with a 3MeO-PCP intoxication [2]. The comparison of molecular network data obtained from patient's urine and from the seven powders contained in the bags found next to the patient allowed us to confirm the consumption of five molecules: 2F-DCK (2-fluorodeschloroketamine), CMC (chloromethcathinone), Nethylhexedrone, 3-MeO-PCP and 3-OHPCP (Figure 1). Moreover, other compounds in relation with 2FDCK, 3-MeO-PCP and 3- OH-PCP have been detected in urine only, which support the possibility of being putative NPS metabolites. Some of them, such as a 3-MeO-PCP glucuronide derivative $(\mathrm{m} / \mathrm{z} 452.228)$, have already been described in a previous work [2]. In addition, data belonging to DCK (deschloroketamine) and 4F-methylphenidate powders were not identified in the urine matrix. This suggests that there was no recent consumption of these substances. Among these NPS, 2F-DCK, 3-OHPCP, 3-MeO-PCP are arylcyclohexylamine derivative providing dissociative effects without altering the respiratory function. $\mathrm{CMC}$ and $\mathrm{N}$-ethylhexedrone are cathinone derivative close to amphetamines. Little is known concerning pharmacokinetic and clinical effects of these compounds. An altered state of consciousness and tachycardia are the most frequent clinical manifestation observed with PCPderivatives [4]. Co-intoxication with similar symptoms involving 3-OH-PCP and N-ethylhexedrone have recently been described [5], which emphasis the risk of multiple NPS consumption, as in our original case where an association of five NPS belonging to two different chemical families is reported with a 
Given the variety of research chemicals derived from ketamine that are increasingly used for recreational purposes, this case illustrates the interest of molecular networking to (i) perform sampleto-sample comparison, (ii) target quantification methods that we do not routinely use and thus (iii) allow proper management to confirm the relevance of the treatment. This visual modelling, although timeconsuming and requiring the management of numerous software programs, facilitates the interpretation and understanding of toxicological analysis results and seems to become a valuable toolbox in the context of intoxication involving NPS.

\begin{tabular}{|c|c|c|c|}
\hline & $\begin{array}{l}\text { Upon arrival on the intensive } \\
\text { care unit } \\
\text { (Day 0) }\end{array}$ & $\begin{array}{l}\text { During admission to the } \\
\text { ICU } \\
\text { (Day 0; } \mathrm{H}+6 \text { ) }\end{array}$ & $\begin{array}{c}\text { Hospital discharge } \\
\text { (Day }+4)\end{array}$ \\
\hline Clinical presentation & $\begin{array}{l}\text { Agitated coma with sweating } \\
\text { and hypertonia. The patient } \\
\text { s weated and was } \\
\text { agitated with } \\
\text { hy pert on ia. He clenched } \\
\text { his teeth, straightened his head } \\
\text { and then relaxed it. } \\
\text { Pupils were in mydriasis, and } \\
\text { mucous membranes were dry. } \\
\text { Cardiological auscultation was } \\
\text { without particularity. } \\
\text { Pulmonary auscultation } \\
\text { showed alternating phases of } \\
\text { respiratory pauses and }\end{array}$ & $\begin{array}{l}\text { The patient was } \\
\text { normotensive, normocardial. } \\
\text { Pupils were in mydriasis, and } \\
\text { there was no reaction to } \\
\text { painful stimulation. Reflexes } \\
\text { were sharp and symmetrical. } \\
\text { The heart sounds were regular } \\
\text { without murmur or rubbing. } \\
\text { Hydroaerobic sounds were } \\
\text { rare. No stigma of prolonged } \\
\text { grounding and compression } \\
\text { point was found. } \\
\text { The patient had transient } \\
\text { oliguria for } 12 \text { hours }\end{array}$ & $\begin{array}{l}\text { The patient was } \\
\text { normotensive, normocardial. } \\
\text { Calm and adapted awakening } \\
\text { with extubation allowed on } \\
27 / 02 \text { with satisfactory } \\
\text { haematosis in ambient air } \\
\\
\text { Psychiatrically, the patient did } \\
\text { not describe a death wish and } \\
\text { was not critical of his drug } \\
\text { use. No indication for } \\
\text { psychiatric hospitalization } \\
\text { was retained after specialized } \\
\text { evaluation. }\end{array}$ \\
\hline $\begin{array}{l}\text { Level of } \\
\text { consciousness }\end{array}$ & $\begin{array}{l}\text { Glasgow coma scale was } \\
\text { fluctuating between } 8 \text { and } 10 \\
\text { (Y4.V1.M1-3) }\end{array}$ & $\begin{array}{l}\text { Richmond Agitation-Sedation } \\
\text { Scale (RASS) : -5 under } \\
\text { sedation }\end{array}$ & Glasgow coma scale : 15 \\
\hline
\end{tabular}


Plasma,

Acetaminophen assay and ethanolemia were negative and plasma lithium concentration was $0.08 \mathrm{mg} / \mathrm{L}[0.5-1 \mathrm{mg} / \mathrm{L}]^{\$}$

In urine, screening found clomipramine, citalopram, mianserine and benzodiazepines (Midazolam, nordazepam) Buprenorphine *

NPS analysis in reference toxicology laboratory $2 \mathrm{~F}-\mathrm{DCK}=147 \mathrm{mg} / \mathrm{L}$
Capillary blood glucose at $1.1 \mathrm{~g} / \mathrm{L}[0.74-1.06 \mathrm{~g} / \mathrm{L}]$

\begin{tabular}{|c|c|}
\hline $\begin{array}{l}\text { Sinus rhythm was at } 86 / \mathrm{min} \text {, } \\
\text { PR interval was at } 150 \\
\text { milliseconds, QRS complex } \\
\text { was normal, axis and QTc } \\
\text { were normal }\end{array}$ & Normal \\
\hline $\begin{array}{l}\text { Symmetrical, poorly reactive } \\
\text { tracing, with no sign of } \\
\text { epilepsy }\end{array}$ & - \\
\hline Normal & - \\
\hline - & - \\
\hline - & - \\
\hline $30 \%$ & - \\
\hline $\begin{array}{l}\mathrm{pH}: 7.46[7.35-7.45], \mathrm{pCO} 2: \\
34 \mathrm{mmHg}[35-45 \mathrm{mmHg} \text {, } \\
\mathrm{pO} 2: 184 \mathrm{mmHg}[80-100 \\
\mathrm{mmHg}], \text { bicarbonates: } 24 \\
\mathrm{mmol} / \mathrm{L}[23-27 \mathrm{mmol} / \mathrm{L}] \text {, } \\
\text { lactates: } 1.4 \mathrm{mmol} / \mathrm{L}[<1.3 \\
\mathrm{mmol} / \mathrm{L}], \mathrm{CPK}: 42,000 \mathrm{IU} / \mathrm{L} \\
{[32-308 \mathrm{IU} / \mathrm{L}] \text { (without }} \\
\text { creatinine elevation). ASAT } \\
\text { was at } 5 \text { times normal values } \\
\text { without cholestasis or ionic } \\
\text { disorder. }\end{array}$ & $\begin{array}{l}\text { No ionic disorder } \\
\text { No coagulation abnormalities }\end{array}$ \\
\hline
\end{tabular}

Plasma,

Nordazepam at $0.11 \mathrm{mg} / \mathrm{L}$ $[0.2-1.8 \mathrm{mg} / \mathrm{L}]^{*}$, clomipramine at $0.03 \mathrm{mg} / \mathrm{L}$ $[0.02-0.25 \mathrm{mg} / \mathrm{L}]^{*}$

Midazolam, nordazepam and mianserine were below the low limit of quantification $\left(\right.$ LLOQ) ${ }^{*}$

Plasma,

3-OH-PCP, 3-MeO-PCP, $\mathrm{CMC}$ and $\mathrm{CMC}=48 \mathrm{mg} / \mathrm{L}$ 3-MeO-PCP $=1100 \mathrm{mg} / \mathrm{L}$ 3-OH-PCP $=12085 \mathrm{mg} / \mathrm{L}$ $\mathrm{N}$-ethylhexedrone $=165 \mathrm{mg} / \mathrm{L}$ the LLOQ

Absence of 2F-DCK 
Table 1: Clinical and biological parameters of the patient at the arrival of the mobile medical emergency unit and in the intensive care unit. * : LC/MS method, \$ : immunoassay, [normal range].

Figure 1: Molecular network comparing the urine sample with the powders found near the patient. DCK: Deschloroketamine, 2F-DCK: 2-fluorodeschloroketamine, CMC: chloromethcathinone, 4-FMPH: 4fluromethylphenidate, 3-MeO-PCP: 3- 6 methoxyphencyclidine, 3-OH-PCP: 3-hydroxyphencyclidine. The molecular network displays spectral high resolution mass spectrometry data acquired during analysis where nodes are labelled with the exact mass of ions corresponding to compounds. Nodes were linked together in clusters according to their spectral similarities. The links between the nodes shows mass shifts that could correspond to biotransformation reactions and can thus lead to the identification of putative metabolites. Using multi-matrix approach, the area of different color in each node represent concentrations of the corresponding compound in each sample in a semi-quantitative manner.

Funding:

No funding to declare

Conflict of interest:

The authors declare that there is no conflict of interest

Informed consent:

Informed consent was obtained from the patient

Acknowledgments:

We would like to thank MB Guilvic et kristina for English language editing of the manuscript. 
References

[1] Weng T-I, Chin LW, Chen L-Y, Chen J-Y, Chen G-Y, Fang C-C. Clinical characteristics of patients admitted to emergency department for the use of ketamine analogues with or without other new psychoactive substances. Clin Toxicol 2020:1-4. https://doi.org/10.1080/15563650.2020.1826506. [2] Allard S, Allard P-M, Morel I, Gicquel T. Application of a molecular networking approach for clinical and forensic toxicology exemplified in three cases involving 3-MeOPCP, doxylamine, and chlormequat. Drug Test Anal 2019;11:669-77. https://doi.org/10.1002/dta.2550.

[3] Vincenti F, Montesano C, Di Ottavio F, Gregori A, Compagnone D, Sergi M, et al. Molecular Networking: A Useful Tool for the Identification of New Psychoactive Substances in Seizures by LCHRMS. Front Chem 2020;8:572952. https://doi.org/10.3389/fchem.2020.572952.

[4] Berar A, Allain J-S, Allard S, Lefevre C, Baert A, Morel I, et al. Intoxication with 3- MeO-PCP alone: A case report and literature review. Medicine (Baltimore) 2019;98:e18295.

https://doi.org/10.1097/MD.0000000000018295.

[5] Dunlop LC, Wood D, Archer J, Hudson S, Dargan P. Severe Toxicity to the New Psychoactive Substances 3-Hydroxyphencyclidine and N-Ethylhexedrone: an Analytically Confirmed Case Report. J Med Toxicol 2020;16:67-70. https://doi.org/10.1007/s13181-019- 00734-x. 